\title{
Deutsche Afrika-Gesellschaft: Symposium on the Present Position and Future Tasks of British African Studies
}

A symposium on the present position and future tasks of British African Studies was held in Cologne on 18 and I9 June, under the auspices of the Deutsche Afrika-Gesellschaft. Professor W. Manshard of the University of Giessen and Professor Daryll Forde, Director of the International African Institute, served as the chairmen of the meeting. Papers on a wide variety of topics were read and discussed during the sessions which were attended by over a hundred participants from many German universities and other institutions.

The chairmen and speakers at the several sections of the symposium were as follows:

Soil Science: Professor Dr. W. Kubiena, Hamburg-Reinbek; Professor E. W. Russell, Reading.

Botany: Professor Dr. H. Walter, Stuttgart-Hohenheim; Dr. J. P. M. Brennan, Kew. Geography: Professor Dr. W. Manshard, Giessen; Professor R. W. Steel, Liverpool. Agriculture: Professor Dr. H. Wilbrandt, Göttingen; Mr. R. J. M. Swynnerton, London. Veterinary Medicine: Dr. Dr. h. c. R. Wetzel, Giessen; Professor A. Robertson, Roslin. Human Medicine: Professor D. H. Vogel, Hamburg; Professor A. W. Woodruff, London.

Economics: Professor Dr. Dr. h. c. Stucken, Erlangen; Dr. D. Rimmer, Birmingham. African History: Professor Dr. R. v. Albertini, Heidelberg; Professor J. D. Fage, Birmingham.

Social Anthropology: Professor D. Forde, London; Professor K. L. Little, Edinburgh. Linguistics: Professor Dr. J. Lukas, Hamburg; Professor A. N. Tucker, London.

Religious Studies: Professor Dr. E. Dammann, Marburg; Dr. R. G. Lienhardt, Oxford. African Law: Professor Dr. Häfelin, Zürich; Professor A. N. Allott, London.

Political Science: Doz. Dr. F. Ansprenger, Berlin; Dr. S. K. Panter-Brick, London.

The papers presented at the symposium are being prepared for early publication, with short introductions contributed by the chairmen of the respective sections.

\section{Methods and Objects of Urban Research in Africa}

A CONFERENCE on Methods and Objectives of Urban Research in Africa, sponsored by the Joint Committee on African Studies of the American Council of Learned Societies and Social Science Research Council, was held on I-3 April at airlie House in Warrenton, Virginia. Its purpose was to stimulate American inter-disciplinary interest in African urban phenomena.

The sessions were devoted to discussion of pre-circulated papers on relevant research work by participants. Areas of concurrence of disciplinary interest were high-lighted, experience with various methodologies was communicated, and research horizons broadened. Papers prepared for the sessions included : ' Comparative Analysis of Processes of Modernization', by Daniel Lerner; ' Motives and Methods: Reflections on a Study in Lagos', by Peter Marris; 'Urban Father-Child Relationships: an Exploration of Yoruba Culture Change', by Robert LeVine (Co-Authors, Nancy McGowen and Constance Rae Fries); ' Urbanization, Type of Descent and Child-Rearing Practices ', by Remi Clignet; ' OptimumSize City Theory and Africa', by Joseph Spengler; ' Urbanization and Economic Growth: the Case of 'Two Settler Communities in Africa', by William Barber; ' Migration Status in 